other patients. When not in use the observation area is locked off and not staffed.

The creation of such 'observation areas' is dependent on the institution having adequate space to put aside a lounge area for only intermittent use. This capability may be lacking in facilities where space is at a premium. The concept is, however, worth exploring further, as any mechanism which lessens the need for seclusion is highly desirable.

Norvic Clinic

C. M. GREeN

Norwich NRI $4 L J$

\section{Diogenes syndrome}

\section{DeAR Sirs}

The description given by Drs Anderson and Bach-Norz (Psychiatric Bulletin, 1991, 15, 574) of an elderly woman living in extreme squalor, hoarding objects for no useful purpose and refusing all offers of help sounds like that of the Diogenes syndrome.

An individual showing the syndrome is typically untidy, unsavoury and often insanitary and psychiatrists may be asked by social workers, housing departments, general practitioners and/or neighbours to take away such a blot on the landscape.

My own belief is that psychiatrists should treat the sick and not act as agents of social control. If this lady presents a danger to the public health or to the safety of buildings then these dangers can be readily dealt with by well established procedures without any need to invoke the Mental Health Act perhaps inappropriately. It may be that her house has not been made safe because the relevant authorities do not want her to return to it and much prefer to have her out of sight.

On an entirely separate point, may I ask what is the difference between deceit and deception. My dictionary gives "deceit-act of deceiving" and "deception-act of deceiving".

\section{V. COAKLEY}

Whiston Hospital

Prescot, Merseyside L35 5DR

\section{Psychiatry in war}

DeAR SIRS

I was pleased to learn that my former colleague, $\mathrm{Dr}$ Gamble, returned safely from his exploits in the Gulf (Psychiatric Bulletin, 1991, 15, 505). He trusts that the NHS will "have little to do in the wake of this war". Those of us serving with the Forces at the time of the Falklands war remember similar sentiments being expressed then about the apparent lack of psychiatric casualties, but we now know that the hidden morbidity was substantial (James \& Lovett, 1987).

Since leaving the Army, I have come across many anecdotal case reports from civilian colleagues treating Falklands veterans suffering from psychological problems consequent upon that war. I have also personally seen many veterans from past wars who never came to formal psychiatric attention at the time but suffered nevertheless, helped where possible by the Ex-Services Mental Welfare Society. I would think it unlikely that the Gulf War will be different in this respect. Many soldiers will have been involved in burying large numbers of Iraqi dead, and this places them at risk in a similar way to those of the rescue services who dealt with the dead from the Zeebrugge, Lockerbie and Kings Cross disasters.

The Gulf war has already had an impact on my work. Several patients, veterans of past conflicts, reported an increase in intrusive memories and flashback phenomena when the Gulf war was at its height, provoked by the vivid television images from the desert. I suspect that my experience here is by no means unique. I would be surprised if in time, further work more directly related to the Gulf conflict does not come the way of NHS practitioners.

Rutson Hospital

G. E. VINCENTI

Northallerton

North Yorkshire DL78EN

\section{Reference}

JONES, G. \& LOVETT, J. (1987) Delayed psychiatric sequelae among Falklands war veterans. Journal of the Royal College of General Practitioners, 37, 34-35.

A list of experts who can give advice to individuals suffering from post-traumatic stress disorder resulting from situations such as the Gulf War is available from Vanessa Cameron at the College.

\section{Services the consultant in mental handicap provides}

\section{DeAR SiRs}

In recent years the demedicalisation of mental handicap has raised the questions of what the consultant in mental handicap does and where there is a need for such posts. From the points of view of practical work, audit and business planning, it is useful to record what tasks and services can be performed or provided only by the consultant. The following pilot list shows that there is still a range of activities that only the consultant can do.

Psychiatric history taking, examination, assessment, diagnosis, treatment, prognosis, of outpatients referred by general practitioners, other consultants and community services; responsibility for overall treatment of in-patients under the consultant's care and co-ordination of their rehabilitation, resettlement and discharge; provision of psychiatric notes, reports, letters, including reports 